УДК 338.49

DOI: https://doi.org/10.37320/2415-3583/9.5

\author{
Костинець Ю.В. \\ кандидат економічних наук, доцент, \\ Національна академія управління \\ ORCID: https://orcid.org/0000-0001-6427-675X
}

\title{
ЦИФРОВІЗАЦІЯ ЯК ЗАСІБ РЕАЛІЗАЦІЇ КОНЦЕПЦИЙ ІНДИВІДУАЛІЗОВАНОГО ТА СЕГМЕНТОВАНОГО МАРКЕТИНГУ НА РИНКУ ТУРИСТИЧНИХ ПОСЛУГ
}

\begin{abstract}
У статті визначено основні особливості цифровізації ринку туристичних послуг та використання основних uџифрових інструментів у конщепщіях індивідуалізованого та сегментованого маркетингу на ринку туристичних послуг. Здійснено розподіл иифрових інструментів індивідуалізованого та сегментованого маркетингу. Визначено основні переваги, недоліки та ичифрові інструменти індивідуалізованого маркетингу та маркетингу сегментів для споживачів і підприємств. Досліджено еволючію інформаційних систем взаємодї з клієнтами та партнерами на ринку товарів і послуг та еволюцію використання цифррових інструментів маркетингу на ринку туристичних послуг. Визначено основні завдання автоматизованої системи взаємодії зі споживачами та партнерами на ринку туристичних послуг. Зроблено висновки щэодо перспектив використання изифрових технологій на ринку туристичних послуг.
\end{abstract}

Ключові слова: ичифровізація, діджиталізація, ринок туристичних послуг, індивідуалізований маркетинг, клієнтоорієнтований маркетинг.

Постановка проблеми. Цифровізация, або діджиталізація, є основою для розвитку сучасного бізнесу. В умовах нової економіки, жорсткої конкуренції, швидкого старіння технологій, професій, ідей, проникнення Інтернету в усі частини економіки діджиталізація вийшла на новий рівень важливості для бізнесу, суспільства та держави. Для підтримки конкурентоспроможності підприємства підприємствам необхідно використовувати можливості діджиталізації за всіма можливими напрямами та формами: клієнтський досвід; партнерство та колаборація; робота 3 даними; впровадження інновацій; HR стратегія та культура; управління цінністю тощо. Компанії стали активно брати на озброєння технології автоматизації бізнес-процесів, упроваджувати інструменти $\mathrm{CRM}+\mathrm{BPM}$ під час формування управлінської концепції, тому для визначення стратегічних перспектив розвитку ринку туристичних послуг у цифровій економіці доцільно розглянути питання еволюції використання цифрових технологій у процесі реалізації концепції індивідуалізованого масового маркетингу.

Аналіз останніх досліджень і публікацій. Поняття цифрової економіки складне і багатогранне, й у науковому середовищі нині немає консенсусу в тому, що слід розуміти під цим явищем. Спроби систематизувати основні поняття, пов'язані із досліджуваними явищами, зроблені в роботі О.В. Даннікова та К.О. Січкаренко. 3 урахуванням того, що в Україні лише відбувається становлення цифрової економіки, необхідно відзначити, що визначення впливу цифровізації на розвиток туристичної індустрії та підприємств туристичної галузі здійснено в окремих дослідженнях вітчизняних фахівців, зокрема Н.В. Садової.

Мета статті полягає у визначенні особливостей цифровізації як засобу реалізації концепцій індивідуалізованого та сегментованого маркетингу на ринку туристичних послуг.

Виклад основного матеріалу. Ринок туристичних послуг є яскравим прикладом ринку, на якому цифрові інформаційні технології мають широке поширення. В аспекті діджиталізації фактично даний ринок $\epsilon$ піонерною сферою національної економіки, де цифрові технології активно впроваджені в діяльність як глобальних корпорацій, так і невеликих гравців ринку.

Сьогодні найважливішим ресурсом будь-якого підприємства, здатним значно вплинути на підвищення його конкурентоспроможності, інвестиційної привабливості та капіталізації, є корпоративні інформаційні ресурси і знання. Однак інформаційні технології не здатні повністю скасувати виробничий процес, ліквідувати конкурентів і право людини приймати остаточне рішення. Можна говорити про інтенсифікацію всіх процесів діяльності підприємства в єдину інформаційну систему. Змінився сам інструментарій в управлінні компанією, який вплинув на всі бізнес-процеси, пов'язані $з$ діяльністю менеджерів: планування, організацію, керівництво, контроль.

Сучасна техніка допускає можливість розвитку маркетингу по новому шляху. На практиці все ширше використовуються бази даних для роботи 3 клієнтом та партнером у діалоговому режимі. Підприємства включають діалогові бази даних в інформаційні системи управління, як тільки скорочується їх інформованість про ринок. 
Вираз «індивідуалізований масовий маркетинг» $є$ вдалим перекладом на французьку мову англійського терміна one-to-one marketing. Тим не менше визначення «індивідуалізований» вибрано досить довільно. Насправді підприємство не може повністю знати про всі індивідуальні вимоги масової клієнтури передусім через величезні витрати, необхідні для цього. У рамках «прямого» маркетингу сегментовані групи або сукупності груп клієнтів користуються стандартизованими пакетами послуг.

Концепція індивідуалізованого маркетингу, представниками якої $€ \mathrm{I}$. Лінтон, Д. Пеппер та М. Роджерс [3, с. 34], передбачає можливість відходу маркетингу від ключової концепції «сегментування» в бік одного клієнта як самостійного ринкового сегмента. Погоджуємося 3 тезою, що «як індивідуалізований маркетинг, так і маркетинг сегментів мають певні переваги та недоліки для споживачів і підприємств. Індивідуалізований маркетинг застосовується значно рідше, що зумовлено не тільки значними витратами виробників, а й неготовністю споживачів пред'явити індивідуалізовані потреби» [7, с. 34]. Основні переваги, недоліки та цифрові інструменти індивідуалізованого маркетингу та маркетингу сегментів для споживачів та підприємств наведено на рис. 1.

Значну роль у формуванні індивідуалізованого маркетингу відіграють діалогові бази даних взаємодії з клієнтами та партнерами (CRM та PRM). Дуже важливим і суперечливим сьогодні $\epsilon$ питання про те, чи призводить використання таких баз даних до розроблення концепції маркетингу «один на один». Необхідно відзначити, що діалогові бази даних не можуть працювати ефективно доти, доки відповідний споживач або сегмент споживачів не відреагує позитивно на стимулюючі дії компаній.

Побудова взаємодії з клієнтами та партнерами $\epsilon$ одним із головних завдань функціонування внутрішньокорпоративної системи, що використовується на ринку туристичних послуг. Також така система повинна давати змогу зберегти клієнтську та партнерську бази даних й історію взаємовідносин зі своїми клієнтами та партнерами (готелі, перевізники, туроператори та агенти). Це важливий чинник формування лояльності споживачів та партнерів, оскільки, як і в будь-якому іншому бізнесі, постійні клієнти і надійні партнери, лояльні до конкретного суб'єкта туристичного бізнесу, є головним чинником ефективної та успішньої діяльності на ринку туристчиних послуг. Сьогодні в умовах дуже швидкої цифровізації для управління взаємовідносинами 3 клієнтами та партнерами переважна більшість суб'єктів ринку туристчиних послуг використовує сучасні інтегровані CRM-системи (Customer Relationship Management) та PRM-системи
(Partner Relationship Management), що дають змогу отримувати максимум інформації про клієнта або партнера в момент спілкування з ним.

Широке впровадження цифрових технологій формує сприятливе середовище для існування та розвитку індивідуалізованого маркетингу, даючи змогу працювати основним цифровим інструментам як інструментам індивідуалізованого маркетингу, наприклад йдеться про чат-боти, рекламу в месенджерах та рекламний контент, який вибирається для конкретного споживача відповідно до його пошукових запитів та вподобань у соціальних мережах завдяки сучасним алгоритмам пошукових систем та соцмереж.

Основними завданнями автоматизованої системи взаємодії зі споживачами та партнерами на ринку туристичних послуг в умовах цифровізації суспільного життя та економічних відносин мають бути:

- існування можливості аналізу та прогнозування основних чинників кон'юнктури ринку туристичних послуг;

- можливість здійснення дослідження основних тенденцій розвитку ринку туристичних послуг та визначення трендів реалізації туристичних продуктів та послуг;

- можливість виявлення системи взаємозв'язків між чинниками впливу на стан та тенденції розвитку ринку туристичних послуг;

- формування інформаційної бази для дослідження конкурентоспроможності туристичних продуктів та послуг на основі порівняльного аналізу;

- автоматизоване розроблення прогнозів попиту на туристичні продукти та послуги;

- автоматизоване розроблення стратегій маркетингу;

- автоматизація зв'язку між субєктами ринку туристичних послуг.

Важливим аспектом створення та організації функціонування автоматизованої системи взаємовідносин між споживачами та партнерами на ринку туристичних послуг $\epsilon$ завдання підтримки цілісності та безпеки інформації про клієнтів та партнерів. Будь-яка компанія, яка прагне для більш ефективної взаємодії з клієнтом або партнером зібрати максимум інформації про нього, повинна подбати про нерозповсюдження цих даних, причому захист приватної інформації про клієнтів та партнерів має відповідати Загальному регламенту захисту даних Європейського Союзу, який відомий як GDPR [8] (General Data Protection Regulation).

Висновки. Таким чином, підсумовуючи, можемо зробити висновок про те, що концепція індивідуалізованого маркетингу допускає можливість відходу від маркетингу, спрямованого на ринковий сегмент, у бік маркетингу, який буде 


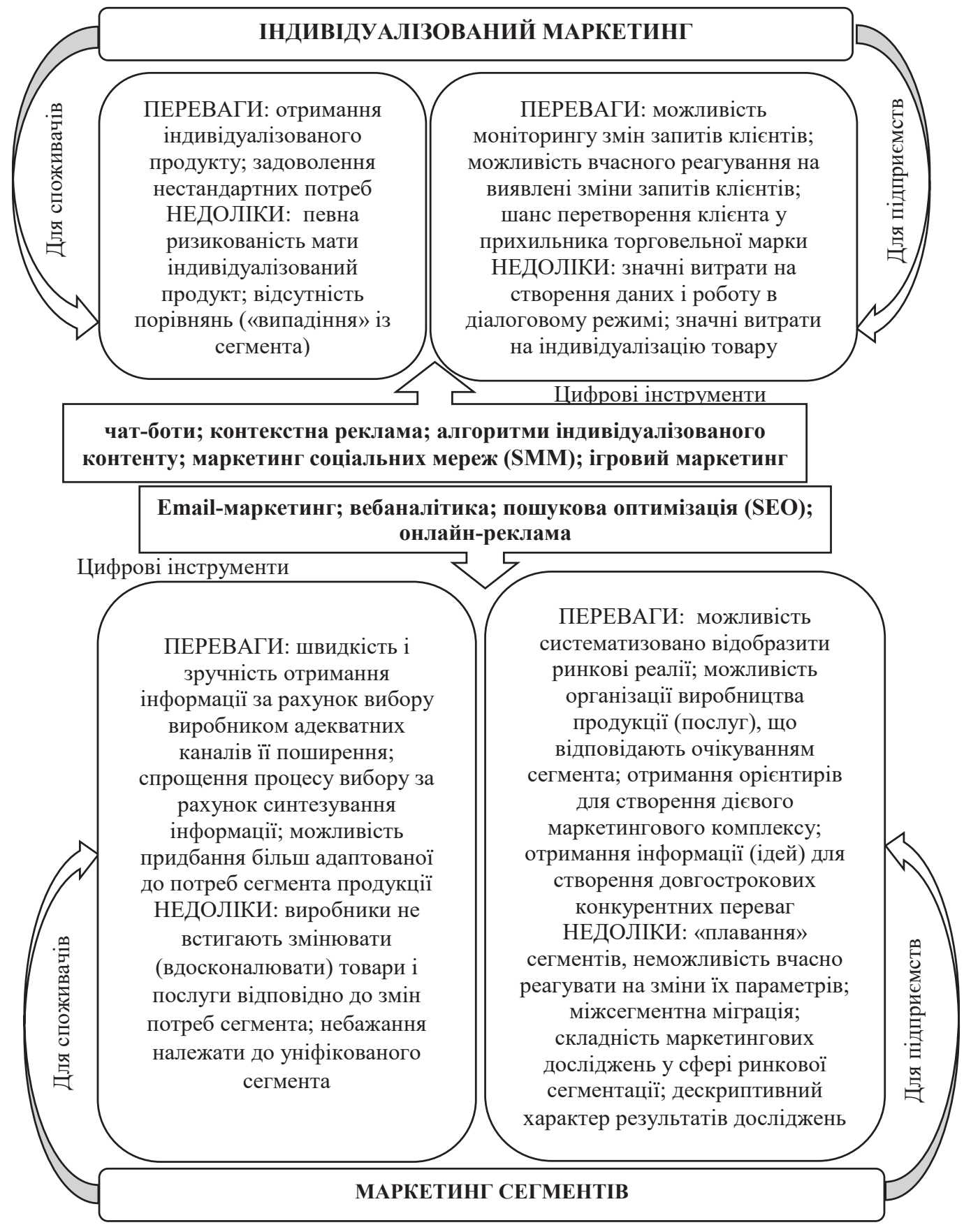

\section{Рисунок 1 - Основні переваги, недоліки та цифрові інструменти індивідуалізованого маркетингу та маркетингу сегментів для споживачів і підприємств}

Джерело: складено автором за [4, с. 34; 7, с. 35]

спрямований на одного клієнта як самостійний окремий ринковий сегмент. У результаті нами наведено порівняльну характеристику індивідуалізованого маркетингу та маркетингу сегментів.

Окрім того, ми дослідили процес еволюції використання цифрових інструментів маркетингу на ринку туристичних послуг та дійшли висновку, що широке впровадження цифрових технологій формує сприятливе середовище для існування та розвитку індивідуалізованого маркетингу, даючи змогу працювати основним цифровим інструментам як інструментам індивідуалізованого маркетингу, що стосується таких інструментів, як чатботи та контекстна реклама.

По-друге, ми визначили, що PRM-система та CRM-система - це стратегічна основа постцифрового маркетингу, оскільки саме ці системи мають стати основою формування індивідуалізованого маркетингового контенту для кожного споживача туристичних послуг. 


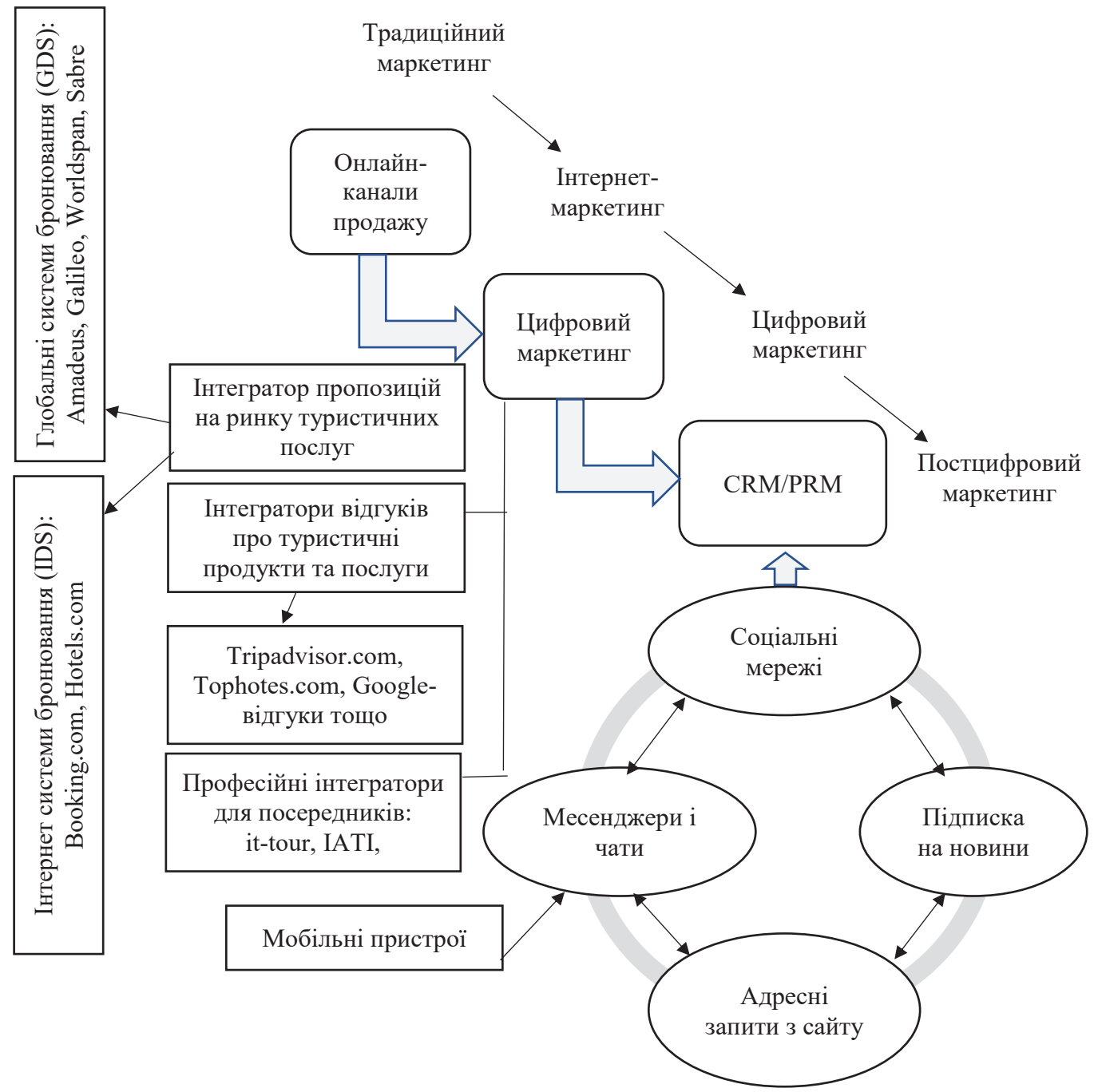

Рисунок 2 - Еволюція використання цифрових інструментів маркетингу на ринку туристичних послуг

Джерело: складено автором

\section{Список використаних джерел:}

1. Данніков О.В., Січкаренко К.О. Концептуальні засади цифровізації економіки України. Інфраструктура ринку. 2018. № 17. C. 73-80.

2. Діше Дж. CRM-навігатор. Посібник з управління взаєминами з клієнтами / пер. 3 англ. О. Сисоєвої. Київ : Стандарт, 2006. 375 c.

3. Линтон Й. Маркетинг по базам данных. Минск : Амалфея, 2003. 159 с.

4. Организация маркетинга и выбор рыночных сегментов : учебное пособие / Н.А. Осипов и др. Москва : Юпитер, 2005. 290 c.

5. Родигин Л.А. Интернет-технологии в туризме : учебник. Москва : Советский спорт, 2010. 338 с.

6. Садова Н.В. Вплив цифровізації на розвиток туристичної індустрії. Ефективна економіка. 2019. № 9. DOI : 10.32702/2307-2105-2019.9.43.

7. Туніцький Н. Критерії сегментації вітчизняного споживчого ринку елітних меблів. Вісник Київського національного торгово-економічного університету. 2010. № 1. С. 33-42.

8. General Data Protection Regulation (EU GDPR). The latest consolidated version of the Regulation with corrections by Corrigendum, OJ L 127, 23.5.2018, p. 2 ((EU) 2016/679). Source: EUR-lex.

\section{References:}

1. Dannikov O.V, Sichkarenko K. O. (2018) Kontseptualni zasady tsyfrovizatsii ekonomiky Ukrainy. [Conceptual bases of digitalization of economy of Ukraine] Infrastruktura rynku. № 17. st. 73-80.

2. Dishe Dzh. CRM-navihator (2006). Posibnyk z upravlinnia vzaiemynamy z kliientamy [CRM navigator. Customer Relationship Management Guide] / Per. z anhl. O. Sysoievoi. K.: Vydavnytstvo Oleksiia Kapusty pidrozdil "Ahentstva "Standart", 375 s. 
3. Lynton Y. (2003) Marketynh po bazam dannykh. [Database marketing] Mynsk: Amalfeia, $159 \mathrm{~s}$

4. Osypov N. A. (2005) Orhanyzatsyia marketynha у vыbor rыnochnыkh sehmentov [Organization of marketing and choice of market segments] : ucheb. posob. dlia vyssh. ucheb. zaved./ N. A. Osypov y dr. M.: Yupyter, $290 \mathrm{~s}$.

5. Rodyhyn L.A. (2010) Internet-tekhnolohyy v turyzme [Internet technologies in tourism]: uchebnyk. M.: Sovetskyi sport, $338 \mathrm{~s}$.

6. Sadova, N. V. (2019) Vplyv tsyfrovizatsii na rozvytok turystychnoi industrii [The impact of digitalization on the development of the tourism industry]. Efektyvna ekonomika. № 9. DOI: 10.32702/2307-2105-2019.9.43

7. Tunitskyi N. Kryterii sehmentatsii vitchyznianoho spozhyvchoho rynku elitnykh mebliv. [Segmentation criteria for the domestic consumer market for luxury furniture] Visn. Kyiv. nats. torh.-ekon. un-tu. 2010. № 1. S. $33-42$

8. General Data Protection Regulation (EU GDPR). The latest consolidated version of the Regulation with corrections by Corrigendum, OJ L 127, 23.5.2018, p. 2 ((EU) 2016/679). Source: EUR-lex.

National Academy of Management

\section{DIGITALIZATION AS A MEANS OF IMPLEMENTING THE CONCEPTS OF INDIVIDUALIZED AND SEGMENTED MARKETING IN THE TOURIST SERVICES MARKET}

The article identifies the main features of digitalization of the tourist services market and the use of basic digital tools in the concepts of individualized and segmented marketing in the tourist services market. The relevance of the topic is due to the fact that digitalization is one of the main factors for the growth of the world economy in the next 5-10 years. In addition to the direct productivity gains that digital companies receive, there is a chain of indirect benefits of digitalization, such as saving time, creating new demand for new products and services, new quality and value, and more. The purpose of the article is to identify the main aspects of the impact of digitalisation of the economy on the development of marketing in the tourist services market. Distributed digital tools of individualized and segmented marketing. The main advantages, disadvantages and digital tools of individualized marketing and segment marketing for consumers and businesses are identified. The evolution of information systems for interaction with customers and partners in the market of goods and services and the evolution of the use of digital marketing tools in the tourist services market are investigated. The main tasks of the automated system of interaction with consumers and partners in the market of tourist services in the conditions of digitalization of public life and economic relations are determined. Having studied the peculiarities of these systems in the field of tourism, it was found that the basis of successful work of CRM and PRM - system is the storage of all information on interaction with clients and partners in a single database. Distributed digital tools of individualized and segmented marketing. It has been found that the tourist company, which ignores the process of informatization, is losing its advantages. The company, which invests in information technology, benefits, as does the prospects for future development and expansion. Conclusions have been made regarding the prospects of using digital technologies in the tourist services market. The comparative characteristics of individual marketing and segment marketing are given.

Key words: digitalization, tourism market, tourist services market, individualized marketing, client-oriented marketing.

JEL classification: L86, Z32, Z33. 